\title{
Research on Party History Education and Its Practical Significance in Party Building Work in Higher Vocational Colleges
}

\author{
Shuhan Guo \\ Shenzhen Polytechnic, Shenzhen 518000, Guangdong, China \\ Email: 345177617@qq.com
}

\begin{abstract}
As far as higher vocational colleges are concerned, strengthening the party history education research work in the party building work of higher vocational colleges can make the ideological and political education work of higher vocational colleges comprehensively innovate and optimize, and truly integrate the party history education The ideological and political education of higher vocational colleges provides theoretical research basis. In view of this, in the entire party building work of higher vocational colleges, it is necessary to always adhere to the idea of morality and cultivating people during the organization and personnel and party building research work, and focus on innovating the educational philosophy of faculty and staff to study party history. It is also necessary to innovate the communication channels of party history education in higher vocational colleges, focusing on building a good party history education environment for teachers in colleges and universities, so as to make the party building work of higher vocational colleges stable and far-reaching.

Keywords: higher vocational colleges, party building work, party history education, realistic significance, educational methods
\end{abstract}

\section{Introduction}

Telling the story of the party well and passing on the good quality of the party not only has a positive influence and effect on the students of higher vocational colleges, but also has a positive effect on the work of teachers in higher vocational colleges. However, judging from the current form of party history education in party building work in higher vocational colleges, there are still many problems. First, from the perspective of the content of party history education, teachers in higher vocational colleges have certain differences and imbalances in the theoretical understanding of the party. Teachers generally know more about the party's revolutionary historical events, but how do they understand the party? There is little understanding of development and growth, and to a certain extent the effect of college teachers studying party history. The second is that teachers in higher vocational colleges do not pay much attention to party history education research. Not only do they rarely conduct educational research in this area, they invest less energy and time, but also rarely focus on party history education and practical significance. Researching and launching specific study activities has caused some teachers to be prone to a disconnect between theory and practice. Based on this, this article will give examples and discussions from four aspects.

\section{Adhere to the idea of cultivating people by virtue, and innovate the educational concept of the employees to study party history}

From its founding to the present, the Communist Party of China has undergone numerous tests and has gradually developed into a party organization that is currently supported and accepted by the broad masses of the people. It can be said that the establishment of the Communist Party of China is based on the broad masses of the people. It is historical. The inevitable choice. Therefore, in the party building work of higher vocational colleges, if you want to truly seek and explore the significance of party history education, you need to always adhere to the idea of morality and cultivation, and innovate and innovate the traditional education concepts of party history for employees. Optimization. Only in this way can party members and teachers of higher vocational colleges better understand the party's history and provide strong support for the development of higher vocational colleges' education in the new era.

For example, when studying the educational significance of party history in party building work in higher vocational colleges, the following aspects can be used to implement the idea of morality and cultivating people, and to realize the innovation of the educational concept of the employee's study of party history. First, pay more attention to the construction of the concept of educational activities for the faculty and staff of higher vocational colleges to study the history of the Communist 
Party of China, and always adhere to the educational concept of morality and cultivation of people, and implement it in the party building work of higher vocational colleges All aspects of. Second, adhere to the scientific education and teaching concepts. During the party history education research in the party building work of higher vocational colleges for teachers, it is necessary to strictly follow the law of physical and mental development of the faculty of higher vocational colleges and the law of party history education. And use this as the core element of the entire party history education research to promote the orderly development of the party building work of the entire vocational college. Of course, during this period, it is necessary to give full play to the initiative of the faculty of higher vocational colleges to study party history, and strive to enable the faculty of higher vocational colleges to better develop and study the practical significance of party history education, and from the cultural level To continuously enrich and expand the content of party history education activities, and promote the stable development of party building work throughout higher vocational colleges. Third, we must always adhere to the original intention and mission of party history education and research. In the process of studying the practical significance of party history education in party building work in higher vocational colleges, it is necessary to carry out relevant research work from safeguarding the rights and demands of the broad masses of the people. Practice has proved that only if our party governs for the people and what the people want, our country can achieve long-term development.

\section{Innovate campus communication channels and build a better education environment for party history in colleges and universities}

From the school level, guide the faculty of higher vocational colleges to conduct research on the party history produced by the Chinese Communist Party, and find out the role and significance of party history education in the education of students in higher vocational colleges. It can not only persist in higher vocational colleges. The direction of talent cultivation is to implement the fundamental task of Lide Shuren. At the same time, it is also conducive to strengthening the vocational college students' sense of identification with China's socialist road, and has a positive influence and effect on the realization of the great rejuvenation of the Chinese nation. In view of this, it is necessary to innovate the way of spreading party history education in higher vocational colleges, focusing on building a good party history education environment for faculty and students in colleges, so that faculty and staff can participate in higher vocational colleges with a better attitude In the school party building work, the party history education research work will enable students to better receive party history education.

For example, when studying the educational significance of party history of party building in higher vocational colleges, on the one hand, party history education can be regarded as the core content of ideological and political education in higher vocational colleges, and various types of educational practice activities can be organized. For example, faculty and staff in higher vocational colleges can start by cultivating the patriotism of students in higher vocational colleges, pay attention to the proportion of red culture in party history education, and choose more red culture content to carry out party history education to students. Innovate on the basis of inheritance, and then truly let the red cultural content play the role of party history education for students. For example, "Taking Tiger Mountain by Strategy" is a classic work in the red theme repertoire, which contains a strong sense of patriotism. Therefore, when facing such red theme repertoires, teachers need to emphasize to students the need for inheritance and innovation. sex. In addition to insisting on the profound connotations contained in the red-themed works, it is also necessary to insist on respecting the history of revolution and paying attention to the educational function of patriotism. On the other hand, it is necessary to carry out some party history education activities with the theme of red culture and in line with the core socialist values throughout the school from time to time, and encourage and guide students to actively participate in them, and then in the process of actual participation Get educated, improve their ideological, political and moral quality, and maximize the practical significance and role of party history education. For example, faculty and staff can set up columns and topics related to red theme repertoires, build a base for red campus culture and education, and flexibly use school newspapers, radio, television, websites and other advantages to effectively strengthen publicity and education, so as to serve as the foundation for higher vocational colleges. Faculty and students create a good educational environment. In this way, the faculty and students of higher vocational colleges can be subtly nurtured and educated, and the party building work of higher vocational colleges can be carried out in a stable and orderly manner.

\section{Build an information exchange platform, and continuously innovate and optimize the educational form of party history}

Although it is very important for the students of higher vocational colleges to receive party history education, it is also very important to help the faculty and staff of higher vocational colleges to do a good job in analyzing and researching the practical significance of party history education. Judging from the current situation of the faculty and staff in higher 
vocational colleges studying the significance of party history education, some faculty and staff have certain differences in cognition of party history education, not only in terms of funding support, manpower investment, and the establishment of an information exchange platform. The work done in other aspects is not adequate, and the development of relevant research activities is not ideal. The faculty and staff of higher vocational colleges study party history education to a large extent rely on relevant academic lectures. The lack of innovation in the educational concepts to guide the faculty and staff of higher vocational colleges to study party history, and the inadequate related content system, all affect the development of party building work in higher vocational colleges at all times. In order to change this situation and let the party history education in the party building work of higher vocational colleges truly exert its educational value, it is necessary to innovate and optimize the form of party history education, and flexibly use the interactive advantages of modern information technology to build a system for faculty, staff and school students. The information-based interactive platform, so as to use the information-based interactive platform to intensify the communication between faculty and staff, and between faculty and students.

For example, when studying the significance of party history education in party building work in higher vocational colleges, on the one hand, it pays attention to and attaches importance to the relationship between online platforms and party history education in higher vocational colleges, and strives to integrate and interact with each other. On the basis of this educational practice platform, enhance the faculty and staff of higher vocational colleges to study the history of the Communist Party of China, and use the research on the history of the Communist Party of China to find out what is helpful for the students in higher vocational colleges to conduct party history education. And use it to guide the development of ideological and political education for students in higher vocational colleges. On the other hand, it is necessary to perfect and supplement the ways and carriers of party history education in higher vocational colleges. For example, in the process of studying the educational significance of party history, the faculty and staff of higher vocational colleges should strengthen collective lesson preparation, and appropriately add some educational articles on party history to the ideological and political education, so as to help students better understand the Communist Party of China The struggle history of the Communist Party of China has a clear and comprehensive understanding and understanding of the century-old history of the Communist Party of China. In addition, it is necessary to take advantage of the advantages of an information-based interactive platform to use campus websites, broadcasts, public accounts and other methods to publicize and educate students, so that more students will gradually pay attention to and realize the importance of party history education. And is willing to cooperate with the faculty in the college to carry out the party building work of the college.

\section{Improve the professional quality of employees and improve the relevant party history education mechanism}

As the main body of party building work in higher vocational colleges, faculty members are also the main person in charge of party history education research. In order to ensure that party building work in higher vocational colleges can always be carried out in the right direction, it is necessary to strengthen the professionalism of the college's staff and teachers. Training, and strive to improve their party history research ability and education level. Of course, the relevant education guarantee mechanism and evaluation mechanism are also the key to ensuring the smooth development of party building work in higher vocational colleges. Therefore, it is also necessary to pay attention to the construction and improvement of relevant education research mechanisms.

For example, when studying the educational significance of party history in party building work in higher vocational colleges, on the one hand, efforts should be made to improve the professionalism and party history research capabilities of faculty and staff. During this period, it is not only necessary for the faculty and staff of higher vocational colleges to continuously accumulate knowledge of party history, rationally plan party building work, and highlight the characteristics of the times of party building work. At the same time, we need to pay attention to the development of ideological education. Whether the party building work of vocational colleges can proceed reasonably has a great relationship with ideological and political education. Therefore, to ensure the development of party building work in vocational colleges, it is necessary to improve the ideological and political education of vocational colleges. Quality combines party history education with ideological and political education. Of course, the cultivation of the professional qualities of the faculty in higher vocational colleges requires strengthening the training of teachers. The education department or school organizes and invites the faculty and staff of higher vocational colleges to actively participate in the education and training of party history, so that the faculty members of the higher vocational colleges have been promoted and developed in the process of participating in party history education and training. On the other hand, it is necessary to improve the relevant party history education mechanism, and effectively use the education mechanism to manage and regulate the education and teaching behaviors of the faculty and staff of higher vocational colleges, so as to institutionalize and standardize the party history education of the faculty and 
staff in higher vocational colleges, and effectively avoid the possibility of problems during the party building work in higher vocational colleges and during exploration and research of the practical significance of the party history education.

\section{Conclusion}

Generally speaking, in the current party building work of higher vocational colleges, doing a good job in the research and exploration of the practical significance of party history education will not only enable the teachers of higher vocational colleges to continuously strengthen themselves through the research on the history of the Communist Party of China. A sense of identity with the Communist Party of China promotes the self-improvement and development of teachers. At the same time, it can also help teachers in higher vocational colleges to find the correct value goals and direction in life during their teaching period, and use their own values to influence and educate students, so that students gradually become professionals needed by society. Based on this, in the party building work of higher vocational colleges, teachers are required to continuously innovate and optimize the form of party history education, and effectively accelerate the construction of information interaction platforms, so as to use information interaction platforms to intensify communication among teachers. Let the party history education research of higher vocational colleges be endowed with new connotations in the new period. It is also necessary to pay attention to and value the cultivation and improvement of the professional qualities of the faculty and staff in colleges and universities, so as to strengthen the main force of studying party history.

\section{References}

[1] Zhao Yan. The significance and path of party history education to promote party building[J]. China Press, 2020(22): 54-55.

[2] Qin Jichun, He Yanxin. The practical significance and educational strategy of college students studying the theory of the history of the Communist Party of China in the new situation[J]. Journal of Ideological and Theoretical Education, 2016(08): 69-72.

[3] Xie Jun. Research on the Innovation of the Education Model of the History of the Communist Party of China in Contemporary College Students [J]. Education and Occupation, 2012(03): 102-104.

[4] Li Na, Liu Mingxin. Analysis on the Significance and Ways of Strengthening the Party History Education of College Students in the New Situation [J]. Journal of Fuqing Branch of Fujian Normal University, 2019(01):103-107+113. 